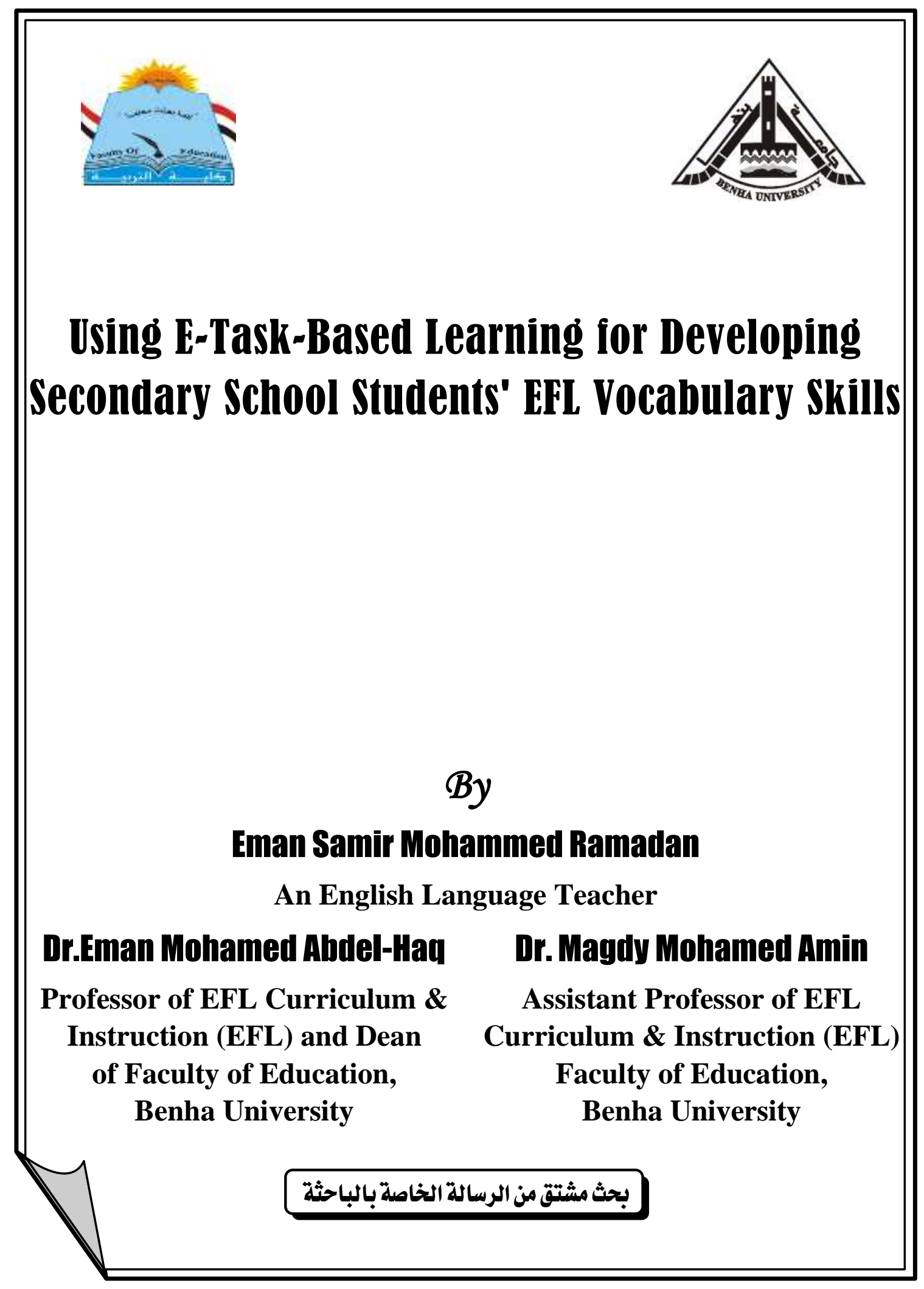




\section{Using E-Task-Based Learning for Developing secondary School Students' EFL Vocabulary Skills}

By

Eman Samir Mohammed Ramadan

An English Language Teacher

\section{Dr.Eman Mohamed Abdel-Hau}

Professor of EFL Curriculum \& Instruction (EFL) and Dean of Faculty of Education, Benha University
Dr. Magdy Mohamed Amin

Assistant Professor of EFL Curriculum \& Instruction (EFL) Faculty of Education, Benha University

\section{Ahstract}

The present study aimed at developing some EFL vocabulary skills among secondary school students using Electronic Task-Based Learning (ETBL). The participants of the study consisted of first year secondary school students enrolled in Subk El-Dahhak Secondary School, in Menoufia Governorate $(\mathrm{N}=25)$. This study adopted one study group preposttest design. Five main tools were used: An EFL Vocabulary Skills checklist required for first year secondary school students, an EFL Pre- test to measure some of the students' vocabulary skills, an EFL Post-test to measure some of the students' vocabulary skills, an EFL vocabulary skills rubric to score students' performance on the EFL vocabulary skills tests and a Teacher's Guide. A quantitative data analysis was conducted. The mean scores of the pre-posttests of the participants of the study were compared by using t-test. ETBL was applied to the participants during the first semester of the academic year 2019/2020. Results of the quantitative analysis showed that the participants' some EFL vocabulary skills were developed significantly as a result of ETBL. Therefore, it can be concluded that ETBL was effective in developing some EFL vocabulary skills among first year secondary school students.

Keywords: EFL vocabulary skills, Electronic Task-Based Learning (ETBL), Secondary school students. 


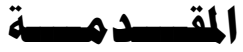

تعتبر اللغة هي واحدة من السمات الرئيسية التي يتميز بها الإنسان. حيث تعتبر ظاهرة اجتماعية وفردية تمكن البشر من التعبير عن مشاعرهم وأفكارهم وثقافتهم. كما أنها أيضـا هي أحد العناصـر المهمـة التي تؤثر على التواصل بين الأفراد. ففي عصر العولمـة حيث أصبح العالم قريـة صغيرة، يهدف الناس إلى تعلم لغة بعضهم البعض. ففي الاوانة الأخيرة تم الاعتراف بللغة الانجليزية كوسيلة للتواصل في جميع أنحاء العالم.

يمثل تعلم المفردات جزء أساسي في تعلم اللغات الأجنبية. فقد عرف \& Neuman \& المفردات على أنها " كلمات يجب أن نعرفها للتواصل بفعالية؛؛ وتتقــم المفـردات الـي الكلمـات في التحـدث (المفـردات التعبيريـة) والكلمـات في الاسـتماع (المفردات الاستقبالية). فالمفردات الإنتاجية هي الكلمات التي يفهمها المتعلمون ويمكنهم نطقها بشكل صـيح واستخدامها بشكل بنـاء في التحدث والكتابـة (Stuart, 2005) بينمـا تشير المفردات الاستقبالية إلى الكلمات التي يتعرف عليها المتعلمون ويفهونها عند استخدامها في السياق، ولكن لا يمكنهم إنتاجها كما أنها هي المفردات التي يتعرف عليها المتعلمون عندما يرون أو يجتمعون في قراءة النص ولكن لا يستخدمونه في التحدث والكتابة (Stuart, 2009). وتوصف العلاقة بين معرفة المفردات واستخدام اللغة بأنها مكملة؛ حيث تتيح معرفة المفردات استخدام اللغـة، وعلى العكس من ذلك، ويؤدي استخدام اللغـة إلى زيـادة في معرفـة المفردات (Nation, 2001). فيكـاد يكون مـن المستحيل تعلم لغـة بدون كلمات حتى أن التواصل بين البشر مبني على الكلمات. ويتفق كل من المعلمين والطسلاب على أن اكتساب المفردات هو عامل مركزي في تدريس اللغة (Walters, 2004). ان تعلم مفردات لغوية جديدة يتم اما من خلال المعلمين داخل حجرة الدراسة، أو من خلال الأقرناء، أو من خلال تدريس المادة التعليمية. فأحيانا لا يحاول الطلاب أن يجدوا مفردات جديدية من خلال التعلم الذاتي وهذا المسلك يسلكه فئة كبيرة من الطلاب. ويعتبر درو المعلم الأساسي في حجرة الدراسـة هو ان يشـرح المفردات الجديديـة للطـلاب وأن يبني لديهم الاسـقاللية في تطوير مهارات المفردات اللغويـة. كما أن الكمات التي يحتجونها في التواصل تعتبر هي القاعدة الأساسية 
لبناء المعرفة (Hedge, 2001). فكلما كان لدي متعلمي اللغة حصيلة كبيرة من المفردات اللغوية كلما كان ذلك أفضل بالنسبة لهم (Susanto, Ab Halim \& Nuwrun, 2019)

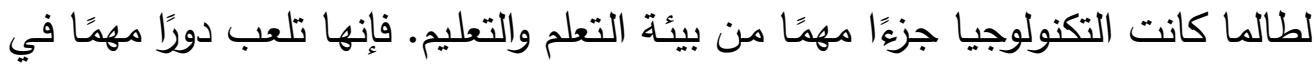
عملية تدريس اللغة الأجنبية. حيث أكد (Ahmadi, 2018) أن استخدام التكنولوجيا أصبح

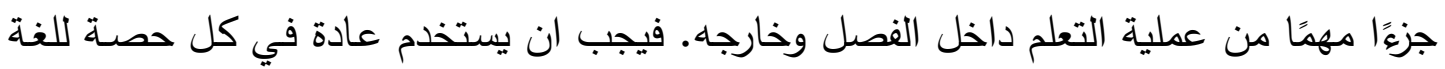

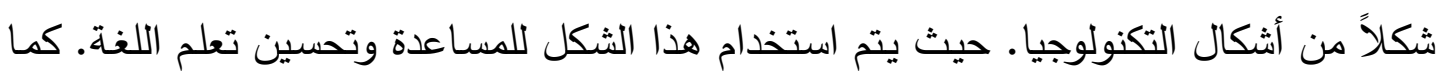

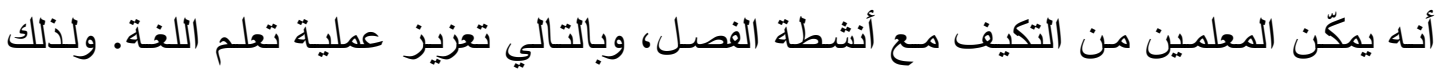
يتضح أن التكنولوجيا لها أهمية كأداة لمساعدة المعلمين على تسهيل تعلم اللغة للمتعلمين.

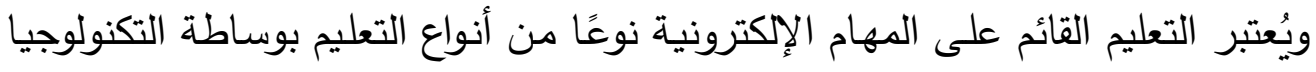

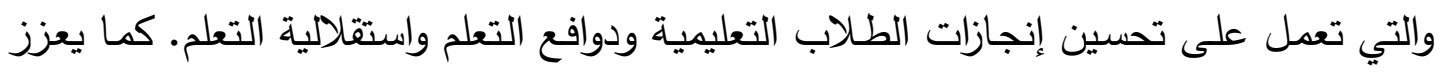
إبداع الطلاب وقيادتهم. وقد أكد (2019, Lopes) على أن التعلم القائم على المهام (TBL)

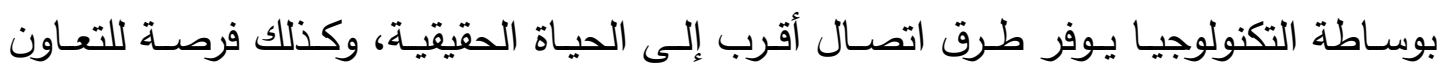

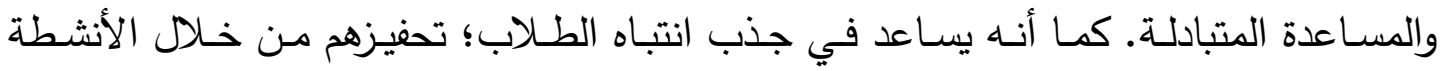

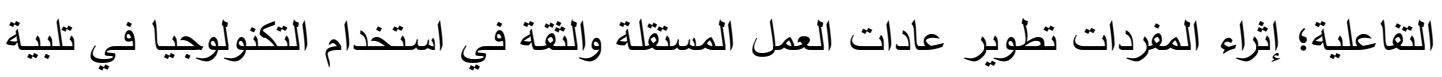
احتياجاتهم التعليمية والتعلم أثناء الاستمتاع.

وقد أكد العديد من الباحثين على أهمية التعلم الإلكتروني القائم على المهام مثل: (Yang, Chen, \& Jeng, 2010; Ganyaupfu, 2013; Tejedo-Romero, Rosa, Corcoles \& Ponce, 2015; Makransky \& Lilleholt, 2018; Ogbonna, Ibezim \& Obi, (2019); Chien, Hwang \& Jong, 2020.)

$$
\text { القائم على المهام الإكترونية في إنه: }
$$

هوفر فرصة للتعامل مع مشكلة نقص سياقات تعلم اللغة والحضور الاجتماعي.

يوفر مشهد تفاعلي يحاكي البيئة الحقيقية.

يمنح الطلاب تجربة تعليمية واقعية لها إمكانات كبيرة لتعزيز تحصيلهة الهيلة التعليمي.

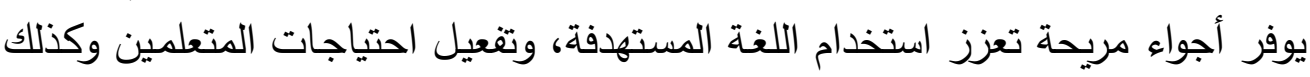
التقاعل مع المهارات.

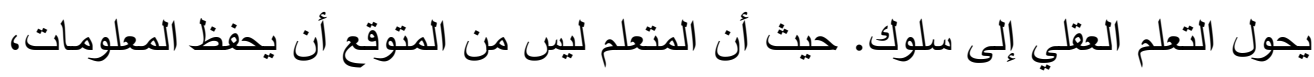

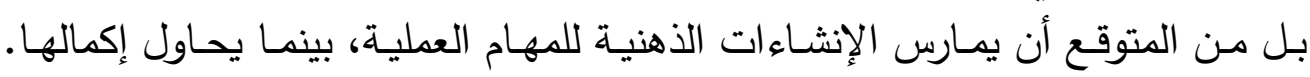

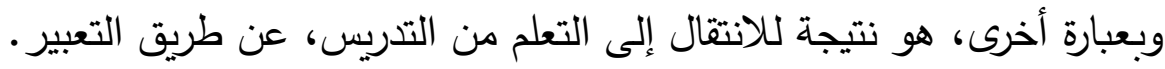




\section{1-Introduction:}

Language is one of the main features that a human being is characterized with. It is considered as a social and individual phenomenon that enables human beings to express their feelings, thoughts and culture. It is also one of the significant elements that affects communication among people. In the age of globalization where the world has become a small village, people aim to teach each other language. English nowadays has been recognized as a means of communication around the globe.

Vocabulary learning is an essential part in foreign language learning. Vocabulary can be defined as "words we must know to communicate effectively; words in speaking (expressive vocabulary) and words in listening (receptive vocabulary)" (Neuman \& Dwyer, 2009, p. 385). Productive vocabulary is the words that the learners understand and can pronounce correctly and use constructively in speaking and writing (Stuart, 2005). Receptive vocabulary refers to words that learners recognize and understand when they are used in context, but which they cannot produce. It is vocabulary that learners recognize when they see or meet in reading text but do not use in speaking and writing (Stuart, 2009).

The relationship between vocabulary knowledge and language use is described as complementary: knowledge of vocabulary enables language use and, conversely, language use leads to an increase in vocabulary knowledge (Nation, 2001). It is almost impossible to learn a language without words; even communication between human beings is based on words. Both teachers and students agree that acquisition of the vocabulary is a central factor in teaching a language (Walters, 2004).

Learning new vocabulary takes place through teachers in class, through classmates, or through teaching material. Students sometimes do not try to find new vocabulary through independent learning, and this phenomenon can be considered as a learning constraint of students. The main role of teachers in the classroom is to explain new words to 
students and build students' independence to develop their vocabulary skills (Hedge, 2001). The words needed in communication are actually basic knowledge. The more relevant words the language learners know, the better for them (Susanto, Ab Halim \& Nuwrun, 2019).

Holmberg and Muwwakki (2020) pointed out that it is important for teachers to bring curiosity in their classrooms, as they also endeavor to do something about it. They need to strive to make their classrooms safe places for students to communicate. They are willing to engage with students in a manner outside of their normative comfort zone. They continuously seek out creative ways to help all their students speak, be heard, learn, and grow. This environment can be achieved through using technology in learning especially through using electronic task-based learning.

Using technology in education is increasingly penetrating the various disciplines. So all modern educational insinuations try to embed the use of technology in their curricula hoping to improve the quality and effectiveness of the learning experience offered to their students. Technology also provides both students and teachers with various ways of networking, sharing and collaborating in real-time.

Electronic -task based learning is considered as a type of technologymediated learning which improves students' learning achievement, learning motivation and learning autonomy. It also enhances students' creativity and leadership. Lopes (2019) asserted that technology-mediated Task- Based Learning (TBL) provides communication contexts closer to real life, as well as the opportunity for collaboration and mutual assistance. It also helps in attracting students' attention; motivating them through interactive activities; enriching vocabulary. In addition, it helps in the development of independent work habits and confidence about using technology in meeting their own learning needs and learning while having fun.

Many researchers asserted the importance of electronic task-based learning such as: Yang, Chen, \& Jeng (2010), Ganyaupfu (2013), Tejedo-Romero, Rosa, Corcoles \& Ponce (2015), Makransky \& Lilleholt 
(2018), Ogbonna, Ibezim \& Obi (2019), Chien, Hwang \& Jong (2020). They mentioned that it:

- provides an opportunity to cope with the problem of lacking language learning contexts and social presence,

- provides an interactive scene that simulates the real environment,

- gives students a realistic learning experience that has great potential for enhancing their learning achievement,

- provides a relaxed atmosphere that enhanced target language use, the activation of learners' needs as well as interaction skills and

- transforms mental learning into behavior. As the learner isn't expected to memorize information, rather he is expected to exercise mental constructions of practical tasks, while trying to complete it. In other words, it is a result of passing to learning from teaching, by expression.

\section{2-Problem:}

In spite of the importance of some EFL vocabulary skills, there is still a lack in the first year secondary students' EFL vocabulary skills at Subk El-Dahhak, Menoufia Governorate. The problem of the study was identified through previous studies, pilot study and personal experience. Therefore, this study was an attempt to use electronic task-based learning (ETBL) to develop some of their EFL vocabulary skills.

To face this problem, the present study attempted to answer the following questions:

1- What are the EFL vocabulary skills required for first year secondary school students?

2- What are the features of the Electronic Task-Based Learning (ETBL) for developing some EFL vocabulary skills among first year secondary school students?

3- To what extent does the ETBL develop some EFL vocabulary skills among first year secondary school students? 


\section{3-Method:}

\section{a) Design:}

This study adopted one study group pre-post test design.

\section{b) Participants:}

The participants of the present study were selected from first year secondary school students; at Subk El-Dahhak, in Menoufia Governorate during the first semester of the academic year 2019/2020. They were selected to be the experimental group. They were (25) females and their age ranged from 16 to 17 years old.

\section{c) Instruments and Materials:}

The present study used five main instruments and materials in order to determine how ETBL was effective:

1- An EFL vocabulary Skills Checklist required for first year secondary school students.

2- An EFL Pre-test to measure students' vocabulary skills before intervention.

3- An EFL Post-test to measure students' vocabulary skills after intervention.

4- An EFL vocabulary skills rubric to score students' performance on the EFL vocabulary skills tests.

5- A teacher's guide.

\section{4- Delimitations:}

This study is delimited to the following:

a) First year secondary school students enrolled in Subk ElDahhak, Menoufia Governorate $(\mathrm{N}=25)$.

b) Some EFL vocabulary skills required for the first year secondary school students.

c) Using WhatsApp.

d) Using English Practice Conversation Application. 


\section{5- Significance:}

\section{To students:}

The significance of the present study lies in helping first year secondary school students to:

a) develop their EFL vocabulary skills.

b) converse freely and fluently.

c) increase their attendance, attitude, and self-reliance.

d) co-create their learning environment.

e) solve real-life problems such as those in their professional contexts.

\section{To teachers:}

The significance of the present study lies in helping teachers to:

a) provide teachers with a new approach for enhancing vocabulary skills.

b) build good teacher-student relationship.

c) be able to overcome the individual differences that their students have.

\section{6-Procedures:}

The following procedures were followed to carry out the present study:

\section{1- Identifying some EFL vocabulary skills required for first year secondary school students through:}

a) reviewing literature and previous studies related to EFL vocabulary skills.

b) preparing a checklist of some EFL vocabulary skills required for first year secondary school students

c) submitting this checklist to a jury to verify its validity.

d) modifying and setting the checklist in its final form according to the jury's suggestions.

\section{2- Identifying the features of the Electronic Task-Based Learning (ETBL) through:}

a) reviewing literature and previous studies related to both ETBL and some EFL vocabulary skills. 
b) identifying the objectives, content, activities, roles of the researcher and students and evaluation techniques that would be used on the treatment.

c) designing the instruments of the study.

d) submitting the instruments to a jury to verify its validity.

e) modifying and setting the instruments in its final form according to the jury's suggestions.

\section{3- Identifying the effectiveness of the ETBL in developing students' some EFL vocabulary skills through:}

a) assigning participants of first year secondary school students into one experimental group.

b) administering the EFL vocabulary skills test to the participants of study (pre-test).

c) implementing the ETBL to the participants of study.

d) administering the EFL vocabulary test to the participants of study after implementing ETBL (post-test).

\section{7- Hypothesis:}

There was a statistically significant difference between the mean scores of the study participants in some EFL vocabulary skills in the preposttest applications in favor of the post application.

The following table presents the students' mean scores, standard deviations, $t$-value and level of significance of the study participants in the pre-posttest applications in favor of the post application.

Table (1): Results of t-test between pre-posttest applications of some EFL vocabulary skills:

\begin{tabular}{||c|c|c|c|c|c|c|c|}
\hline Skill & $\mathbf{N}$ & Application & Mean & S.D & t-Value & D.F & Sig. \\
\hline \hline $\begin{array}{c}\text { Vocabulary } \\
\text { skills }\end{array}$ & 25 & Pre & 10.520 & 1.338 & 22.289 & 24 & 0.01 \\
\cline { 3 - 6 } & Post & 15.000 & 1.555 & 22.01 \\
\hline
\end{tabular}


As shown in table (1), the mean scores of the study participants in the post application of the overall vocabulary skills were higher than their scores in the EFL vocabulary pre-test,where t-value is (22.289), which is significant at the (0.01) level. Consequently, this hypothesis was affirmed.

After introducing the results of the current study statistically, this result is presented using graphs as follows.

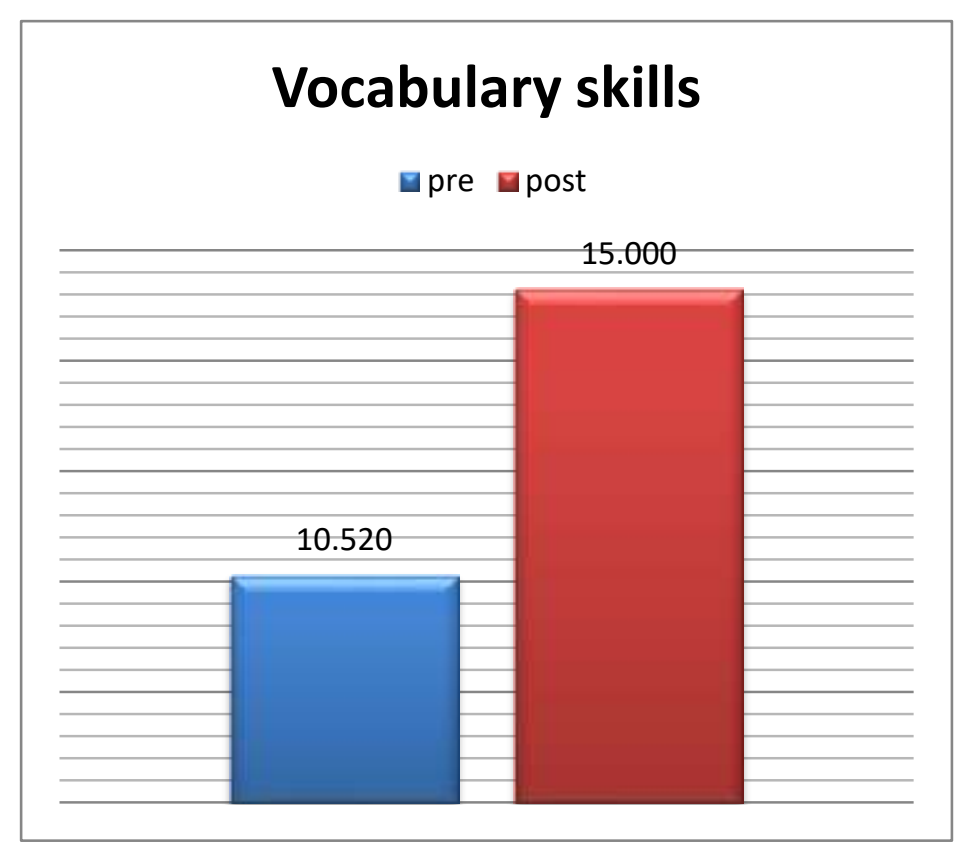

Figure (1): The mean scores of the pre-post assessments of some EFL vocabulary skills of the participants of the study.

Developing the study participants' some EFL vocabulary skills was through the use of some technological materials and activities. The task was "A Plan for a trip to the beach". The task lasted for two sessions in one week. The students were guided by the researcher during three stages of ETBL. The three stages are pre-task, task cycle and language focus. In groups, they gathered information about the topic. They were asked to present the presentation in front of the whole group. Then, they uploaded it on the Conversation Page on What'sApp.

The study participants were asked to share their videos with their group members. They also used English Conversation Practice 
Application. Consequently, the study participants' some EFL vocabulary skills were developed greatly in the post-assessment of the EFL vocabulary test than the pre assessment due to the effect of ETBL.

These results were consistent with some previous studies (e.g. Arora, Joshi, Koshy, \& Tewari (2017), Chien, Hwang \& Jong (2020) which proved the great contribution of ETBL to developing some vocabulary skills

\section{8-Discussion of the findings:}

The findings of the study hypothesis revealed that there was a statistically significant difference between the mean scores of the study participants in overall some EFL vocabulary skills in the pre-test application and the post-test application in favor of the post-application. As indicated in Table (1), the study participants showed more development in their EFL vocabulary skills in the post -assessment than the pre-assessment. Such development supported and confirmed the hypothesis.

This result could be attributed to many factors. The first factor was related to the nature of ETBL, which included some aspects and tools for developing some EFL vocabulary skills. Firstly, ETBL was helpful in: providing authentic content in vocabulary skills, which helped in improving these skills. ETBL also assisted the students to change their concept about learning English language in general and some EFL vocabulary skills in particular; that helped them to turn from passive learners into active learners. Also, ETBL helped the teacher to turn from lecturer into monitor, guider and more helper to the students.

Accordingly, the students become more autonomous and responsible for their learning and this is the ultimate goal of the ETBL. In addition, working in groups helped them to converse freely, learn from each other, and evaluate themselves and the other groups. This- in its turn- may contribute to develop some of the EFL vocabulary skills among first year secondary school students. 


\section{9- Conclusions:}

It can be concluded that the participants' EFL vocabulary skills were developed as a result of receiving ETBL. This means that ETBL was effective in achieving the aim of the present study. The effectiveness of ETBL may be due to depending on one of the new technologies that has gained prominent importance recently. Previous research had proved that technology in general has a significant and effective role in EFL learning and teaching. Accordingly, the starting point from which this study was based was the increasing emphasis on the outstanding role of technology in EFL learning and the great gains from incorporating it into EFL contexts.

The justifications for choosing the variables of the present study are as follows: Firstly, choosing some EFL vocabulary skills was justified by the lack of these skills among the participants of study as revealed by the pilot study and the results of the related studies. Moreover, choosing first year secondary school students was justified by the fact that it is the year at which the students face English as a new paradigm in their life, study English skills in a way they did not encounter before. Therefore, it is not accepted for those students to start their secondary stage with lack in some EFL vocabulary skills.

Accordingly, the researcher began to search for a suitable method for improving such students' EFL vocabulary skills. And due to the proved results of technology in general and ETBL in particular on developing these skills as indicated by previous research, the researcher decided to choose ETBL approach to develop the students' vocabulary skills. In the light of the findings of the present study, the following conclusions can be imbedded: The study participants showed a great development in some EFL vocabulary skills. Consequently, it can be concluded that ETBL was found to be effective in developing some EFL vocabulary skills to the participants. 


\section{0-Recommendations:}

Based on the results of the present study, the following recommendations can be offered:

1- Electronic Task-Based Learning (ETBL) should be implemented in teaching EFL vocabulary skills to students at the second and the third year of the secondary stage.

2- ETBL should be applied not only in EFL vocabulary course but also in all other language skills courses.

3- Teaching should be turned from being teacher-centered to learner oriented in which learners become more involved in and responsible for their learning and become self-autonomous.

4- Self-assessment and peer-assessment should be applied in evaluative system.

5- Teachers and learners should receive advanced training on making use of the benefits of technology.

6- The learning environment should be enthusiastic.

7- The schools' IT infrastructure should receive more attention.

8- Teachers should pay attention to select various tasks that include different patterns of interaction features.

\section{1-Suggestions for further research}

Based on the findings of the present study, the researcher suggests that the following researches should be carried out:

1- Investigating the effect of Electronic Task-Based Learning (ETBL) on improving EFL vocabulary skills among other categories of learners other than the participants of study. 
2- Testing the impact of ETBL on improving other language skills such as listening, reading and writing.

3- Figuring out the effect of ETBL on improving EFL in-service teachers' language teaching skills.

4- Replicating this study to confirm the results of the present study.

5- Investigating the effectiveness of other technology applications on the EFL vocabulary skills among student teachers at the Faculties of Education.

6- Comparing the effect of technology-based approaches versus traditional approaches to develop some EFL vocabulary skills. 


\section{References}

Arora ,S. Joshi, K. Koshy, S. \& Tewari, D. ( 2017). Application of Effective Techniques in Teaching/Learning English. English Language Teaching, 10 (5), pp.34-50.

Chien, S., Hwang, G. \& Jong, M. (2020). Effects of peer assessment within the context of spherical video-based virtual reality on EFL students' English-Speaking performance and learning perceptions. Computers \& Education,146, pp.1-20. Available at http://www.elsevier.com/locate/compedu.

Ganyaupfu ,E.M. (2013). Teaching methods and students' academic performance. International Journal of Humanities and Social Science Invention, 2(9), pp.29-35. Available at https://www.researchgate.net/profile/Ganyaupfu_Elvis_Munyarad zi/publication/264124430_Teaching_Methods_and_Students'_Aca demic_Performance/links/53cf63a50cf2fd75bc59b9d7/TeachingMethods-and-Students-Academic-Performance.pdf.

Hedge, T. (2001). Teaching and learning in the language classroom. Oxford university press Oxford, England, Vol. 106.

Holmberg, C. \& Muwwakki, j.( 2020). Conversation in the classroom. Language Matters,101 (5), pp.25-29.

Lopes, A. (2019). How different are European and American foreign language teachers regarding the use of ICT in task-based language learning? Beliefs, attitudes and practices in the classroom. In C. N. Giannikas, E. Kakoulli Constantinou \& S. Papadima-Sophocleous (Eds), Professional development in CALL: a selection of papers (pp.159-179).Research-publishing.net https://doi.org/10.14705/rpnet.2019.28.877 
Makransky, G., \& Lilleholt, L. (2018). A structural equation modeling investigation of the emotional value of immersive virtual reality in education. Educational Technology Research and Development, 66(5), pp.1141-1164. https://doi.org/10.1007/s11423-018-9581-2

Nation, I. S. P. (2001). Learning vocabulary in another language. Cambridge: Cambridge University Press.

Neuman, S. B., \& Dwyer, J. (2009).Missing in action: Vocabulary instruction in pre-k. The Reading Teacher, 62(5), pp.384-392.

Ogbonna, C. Ibezim, N. and Obi, C. (2019) Synchronous versus asynchronous e-learning in teaching word processing: An experimental approach. South African Journal of Education, 39(2), pp.2-15.

Stuart, W., (2005) : Receptive and productive vocabulary learning : The Effects of Reading and Writing on Word Knowledge. Studies in Second Language Acquisition, 27 (1), pp.33 - 52.

Stuart, W., (2009): Receptive and productive vocabulary size of L2 learners. Studies in Second Language Acquisition, 30 (1), pp.79 - 95.

Susanto,A., Ab Halim, F. \& Nuwrun ,S. (2019). Vocabulary Learning Strategies, Vocabulary Skills, and Integrative Motivation Levels among University Students. International Journal of Engineering and Advanced Technology (IJEAT), 8 (5), pp.323-334.

Tejedo-Romero F, Rosa CP, Corcoles YR \& Ponce AT (2015). Effects of innovative teaching methods on students' academic performance: An empirical study on financial accounting. Junio, 16(2), pp.109-128. https://doi.org/10.14201/eks2015162109128

Walters, J.M. (2004). Teaching the use of context to infer meaning: A longitudinal survey of L1 and L2 vocabulary research'. Language Teaching, 37(4), pp. 243-252.

Yang, J. C., Chen, C. H., \& Jeng, M. C. (2010). Integrating videocapture virtual reality technology into a physically interactive learning environment for English learning. Computers \& Education, 55(3), pp.1346-1356. 